\title{
Why Taxing Consumption?
}

\section{Justifications, Objections and Social Cooperation}

Landes, Xavier

Published in:

Philosophical Explorations of Justice and Taxation

DOI:

10.1007/978-3-319-13458-1_7

Publication date:

2015

Document version

Early version, also known as pre-print

Citation for published version (APA):

Landes, X. (2015). Why Taxing Consumption? Justifications, Objections and Social Cooperation. In H. P. Gaisbauer, G. Schweiger, \& C. Sedmak (Eds.), Philosophical Explorations of Justice and Taxation: National and Global Issues (pp. 101-117). Springer. Ius Gentium Vol. 40 https://doi.org/10.1007/978-3-319-13458-1_7 


\author{
Why Taxing Consumption \\ Justifications, Objections and Social Cooperation' ${ }^{1}$ \\ Xavier Landes, University of Copenhagen \\ xavier.landes@gmail.com
}

This is a draft, pre-proof read, version

The final version has been published in Helmut P. Gaisbauer, Gottfried Schweiger, and

Clemens Sedmak (eds.) (2015), Philosophical Explorations of Justice and Taxation:

National and Global Issues, New York: Springer

And it is available here: http://link.springer.com/book/10.1007\%2F978-3-319-13458-1

\begin{abstract}
Robert Frank is famous for proposing an incremental tax on consumption. His proposition is motivated by the control of positional externalities, i.e. the costs that individuals impose on each other when they consume goods for securing or acquiring social status. A close analysis of Frank's proposition conducts to identify three justifications for a tax on consumption: efficiency, paternalism and equality. This chapter has two purposes. Firstly, it reviews these justifications, highlighting some objections and possible replies. As such, it suggests that reasons based on equality or paternalism are controversial while the invocation of efficiency is actually grounded in an underlying view on social cooperation. Secondly, this chapter advances the idea that an ultimate justification for the choice of specific tax base (consumption, income and wealth) expresses such an underlying view. In other words, the choice of a specific tax base is not totally instrumental, it has some intrinsic moral value too. The chapter ends with a comparison between taxing income and taxing consumption to that respect. It is shown that a tax on consumption raises questions that should be answered by political philosophers.
\end{abstract}

\footnotetext{
${ }^{1}$ I am thankful to Bruno Verbeek and Daniel Halliday for their comments and inputs as well as the participants to the conference on Justice, Taxation and Social Policy organized by the Center for Ethics and Poverty Research at University of Salzburg.
} 
Taxation is the price which we pay for civilization, for our social, civil and political institutions, for the security of life and property, and without which, we must resort to the law of force.

Journal of the House of Representatives of the State of Vermont, October Session, 1851

Taxation is a key component of public policy by generating resources for public goods, social insurance and redistribution. Decisions about taxation may also affect political and social stability by nurturing social unrest and revolutions. Examples are abundant: the American Revolutionary War started with a tax controversy (the 1765 "Stamp Act"), like the French Revolution². In United Kingdom, the project of a poll tax ("Community Charge") contributed to Thatcher's fall in 1990.

Despite the importance of the topic, it has attracted little interest in political philosophy. This is striking when compared to the refined analyses in distributive justice about the use of resources extracted from taxation. Various reasons can explain such neglect. One might argue that no matter how resources are collected, the only relevant question is what to do with them. There is also the view shared by many egalitarians that just contributions are contributions that mirror one's ability to pay or produce (e.g. talents in Rawls), which is supposed to end the discussion.

However, except if one controversially assumes that how public resources are collected does not matter at all, there is space for investigating the normative dimensions of taxation. It is difficult to consider that, for instance, the choice of taxing consumption instead of wealth or income, or to impose a progressive rate instead of a flat one is normatively indifferent. If this point is accepted, a normative theory of taxation has to articulate the following dimensions.

1. Why taxing? Which reasons do public institutions have for collecting part of, what looks like at first sight, individuals' resources?

2. What taxing? What is the "right" tax base, consumption, income or wealth?

3. How taxing? Which rules should be followed when implementing citizens' tax duties?

\footnotetext{
2 The reader may refer to Nicolas Delalande's historical monograph for France (Delalande 2011) and Martin Daunton for United Kingdom (Daunton 2002).
} 
I address here the second question through a discussion of Robert Frank's advocacy for a progressive tax on consumption (Frank 1999, 2007, 2008, 2011). ${ }^{3}$ The methodology is to present Frank's position (first section) and to evaluate three reasons that might support a consumption tax: efficiency (second section), paternalism (third section) and equality (fourth section). When discussing these reasons, income or wealth taxes are not mentioned for the sake of a comparative analysis, but for highlighting the strengths and weaknesses of Frank's position. The paper ends with a brief exposition of the core of the issue: the conception of social cooperation embodied in the choice of a tax base (fifth section). In the fifth section and the conclusion, I claim that political philosophers, especially those interested in distributive justice, need to be more concerned by taxation.

\section{Positional Consumption and Externalities}

Inspired by Thorstein Veblen's seminal work on conspicuous consumption (Veblen 1994), Frank advocates for a steeply progressive tax on consumption. According to him, citizens should pay taxes at a marginal rate that is positively correlated to their amount of consumption: the more they consume, the higher the marginal rate should be.

His proposition is rooted in the observation that individuals are trapped into positional arms race, which produce externalities (i.e. costs imposed to third parties to an original exchange). In the United States and elsewhere ${ }^{4}$, individuals consume too much in general and too much of positional goods in particular, i.e. goods that are mostly demanded for their extrinsic qualities (i.e. for signalling one' status). ${ }^{5}$

Frank's central claim is that consumption is context-sensitive: other individuals' decisions matter in one's consumption. Individuals are influenced by social standards of spending, i.e. the rules about appropriate consumption. This context-sensitivity cannot be reduced to status-seeking alone as some suggest (Botton 2004) since one's relative standing may deeply affect his ability to pursue his life projects and realize his conception of the good (Frank 1999, pp.122-145). People care about their relative standing (determined by their

\footnotetext{
${ }^{3}$ Frank and other authors (e.g. Thomas Hobbes, David Hume, John Stuart Mill, Irving Fisher, Milton Friedman) have advocated for a spending tax, sometimes in replacement of the current tax system.

${ }^{4}$ Positional consumption is present in developing countries too (Solnick et al. 2007; Van Kempen 2009).

${ }^{5}$ Positional goods are 'goods, services, work positions, and other social relationships that are either (1) scarce in some absolute or socially imposed sense or (2) subject to congestion or crowding through more extensive use (Hirsch 1976, p.27)'.
} 
relative spending) because it affects their opportunities in life and the opportunities of people for whom they care (e.g. children, spouse, dependants).

The origin of the problem lies in the positional dynamics that has been accentuated by the dramatic increase of top-incomes since the 1970's whereas low and middle incomes have stagnated or only slightly increased (Frank 2007, pp.7-16). ${ }^{6}$ The crux of the argument is that top-earners strongly influence social standards on appropriate spending in relation to home, clothes, travel, and so forth. 'Expenditure cascades' (Frank 2011, p.61) explain how these patterns spread throughout the society: top-earners' habits are imitated in a less large scale by the income group who is below, whose consumption is imitated by the income group just below, and so forth.

By their spending habits individuals create positional externalities for others: for decades, standards for "decent" home, gifts, clothes, vacation, cars, electronic appliances, and other goods and services have been rising. For instance, according to the National Association of Home Builders, the average size of US houses had almost doubled between 1970 and 2009. So, individuals have been using more resources for keeping up with criteria of socially adequate spending. Individuals would spend too much, at their own detriment. In addition, positional consumption creates prisoner dilemmas where agents are trapped in suboptimal situations.

These situations are suboptimal due to 'positional externalities': everyone's spending increases the pressure on everyone else to adopt the same strategy. ${ }^{7}$ This pressure creates further damages: overwork, wasteful conspicuous spending, pressure to perform, psychological distress, etc. (Frank 1999). These damages result from 'positional arm-races' where most of participants try to outperform (outspend) their competitors. Frank sees this dynamics at work for housing, gifts, vacation, clothing, and so forth. Like for the arms race between Soviet Union and United States during the Cold War (Brams 1985), the increased

\footnotetext{
6 Various authors highlight such dynamics, especially in the American context. For instance, Juliet Schor identifies a 'new consumerism' in the 'national culture of upscale spending' (Schor 1998, p.4) while Oliver James diagnoses an epidemic of 'affluenza' (James 2007).

${ }^{7}$ One may argue that positional externalities and costs from lack of coordination are two different things since the first ones are imposed on individuals who are part of an exchange that has the form of a prisoner's dilemma while the second ones are imposed on individuals who are not part of the exchange (external to the exchange). Such a distinction implies to be able to draw a sharp line between agents involved in an original exchange and outside agents who suffer from the consequences of this exchange. The problem is the impossibity to identify an original exchange or to clearly distinguish between costs stemming from a lack of cooperation and externalities.
} 
spending on housing or cars incurs an adjustment of his immediate surroundings (relatives, friends, colleagues), which propagates further. ${ }^{8}$

Frank's appeal to 'positional externalities' strengthens the case for public intervention, especially in direction to those who are reluctant to state's interference in private matters (Frank 2008; 2011, pp.194-215). Based on John Stuart Mill's harm principle ${ }^{9}$, Frank argues that positional consumption generates a broad array of costs that justify public intervention because they are imposed to third parties. His argument is to add to the loss of welfare, the constraints imposed by individuals on each other and the individuals' incapacity to independently scale down their expenses (Frank 2008, p.1782), which results in the impossibility of reducing the production of externalities in a significant manner.

Frank identifies two levels of positional harms. Firstly, individuals ruin their psychological situation. They do not optimize the happiness potential that could be derived from their material resources. ${ }^{10}$ They get less satisfaction or subjective well-being than they would in at least one attainable alternative (i.e. Pareto improvement is possible).

Secondly, individuals ruin their material situation, both individually and collectively. Individually, expenditure cascades increase positional spending and activities whereas decreasing non-positional consumption and activities (e.g. time spent with friends and family). People save less and become more vulnerable to future adverse events (e.g. unemployment, illness). Less affluent individuals rely on bank credit for keeping up (and counter-balancing the stagnation of their income). Socially, private and public investments are squeezed, jeopardizing public goods and growth. Also, the increased pressure to "keep up with the Joneses" partly explains the current reluctance to taxation.

As a solution, Frank proposes a progressive tax on consumption that will not apply on specific positional goods (contrary to a luxury tax), but on individuals' volume of

\footnotetext{
8 Other illustrations of positional arms-race include sports in US Ivy League universities (Dixit and Nalebuff 1993, pp.225-227), the 'publish-or-perish' dilemma in academia (Landes et al. 2013) or reproductive competition in some animal species (Frank 1999, pp.148-152).

9 ' $[\mathrm{T}]$ he only purpose for which power can be rightfully exercised over any member of a civilized community, against his will, is to prevent harm to others. His own good, either physical or moral, is not a sufficient warrant' (Mill 2003, p.80).

10 Frank assimilates happiness to subjective well-being (constituted by positive, negative affects and life satisfaction) even if he is aware of their difference (Frank 2007, p.18).
} 
spending. ${ }^{11}$ Such a tax will curb positional consumption in particular and consumption in general. If the rates are steep enough, it will cause a decline in top-earners' spending, but also in the spending of lower income classes in virtue of the expenditure cascades. Individuals will be forced to save more, which will be beneficial to private investments and enhance individuals' capacity to cope with adverse events. Finally, more resources will be levied for financing public goods, which will benefit to everyone in the society.

Frank's argument is a mix of at least three different justifications, namely efficiency, paternalism and equality. The subsequent sections will present and discuss the worth of each of them. ${ }^{12}$ Then I will argue that the core of the issue is how to conceive social cooperation. My suggestion is that the choice of a tax base expresses a particular conception of social cooperation.

\section{Efficiency}

Usually economists and philosophers share the view that efficiency is an a-moral concept: it would be silent on the good and the bad, the right and the wrong, of different actions or states of the world. Thus, the efficiency of a social arrangement would be a purely empirical matter. This view is rooted on a division of the intellectual labour between economists, who would deal with factual issues, and philosophers, who would deal with evaluative ones.

This division might have some cogency, but it cannot be denied that the concept of efficiency is partly normative. In order to judge that a given arrangement is efficient, two normative "things" should be decided: (1) what needs to be efficient, i.e. the object of efficiency, and (2) which principles must ground this evaluation, i.e. the rules of efficiency.

(1) The debate on whether Gross Domestic Product (GDP) offers a fair evaluation of socioeconomic performance illustrates the first point (van den Bergh 2010). No doubt that the choice between GDP or alternative indicators such as UNDP's Human Development Index or the Happy Planet Index is to some extent influenced by practical considerations (e.g. data's availability, possibility to sum different aggregates or undertake international comparisons).

\footnotetext{
${ }^{11}$ Individual spending is calculated by deducing savings from income. The practical advantage of this proposal is to avoid the difficulty to define and identify positional goods.

12 I discuss in details the different normative arguments for curbing positionality in another piece (Landes 2013b).
} 
But the choice is normative too since it expresses views about what should be collectively valued (economic growth, education, life expectancy, environment, etc.).

(2) Choosing between different conceptions of efficiency is not axiologically neutral either. For instance, a choice between Pareto and Kaldor-Hicks efficiencies is a choice between a conception that excludes the improvement of the situation of an agent at the expense of another (the so-called "minority sacrifice") - Pareto's conception - and a conception that precisely allows a trade-off as long as compensation is hypothetically possible - Kaldor-Hicks' conception.

Efficiency is a normative concept that allows different interpretations (conceptions). Ultimately, the "what" of Frank's conception (i.e. what should be efficient) boils down to the conditions of social cooperation. In his writings, there are at least three aspects in which implementing a progressive tax on consumption would render social cooperation more efficient: the reduction of positional externalities' "leakage", the maximization of the social output (especially through private and public investments), and the improvement of individuals' satisfaction or happiness.

To that respect Frank is the heir of Welfare Economics that attributes to the state the responsibility of correcting 'market failures' (Baumol 1952, 1972), i.e. to enhance welfare. However his use of Mill's harm principle expresses the additional argument that public intervention is ultimately justified by the prevention or correction of harms imposed on others (Frank 2008). Since market failures imply imposed harms to others, the state ought to intervene. ${ }^{13}$ Pigovian taxation is the classical tool. It consists in charging a tax on the emitters of the negative externalities (Landes 2013a). Frank's originality is to stretch the concept of externalities and Pigouvian taxation for including positional dimensions.

However, Frank does not clearly define the concept of positional externalities in his writings. A plausible interpretation is that a positional externality consists in the negative variation of the status of a given individual that results from an initial interaction of which he has not been part (implying that he has not agreed on the terms of this interaction), inducing two kinds of costs: material ones (e.g. high consumption, low savings, or under-financing of

\footnotetext{
${ }^{13}$ Like many, Frank oscillates between two uses of externalities. The first consists in weighting the current situation against an ideal for identifying the divergences, i.e. the famous "market failures". The main reproach against that view is that it succumbs to the 'Nirvana fallacy' (Demsetz 1969), which is to compare actual situations to hypothetical, non-feasible, alternatives. The second use is more pragmatic since it is only to identify actual harms and redress/prevent them on a case-by-case basis.
} 
public goods like roads, bridges, hospitals, etc.) and psychological ones (e.g. reduced wellbeing and happiness).

By contrast, efficient cooperation is characterized by limited "positional leakage", high private/public investments and high individual satisfaction/happiness. However, if the objective were to reduce or suppress positional externalities, why a (incremental) tax on consumption is more efficient than, say, a (incremental) tax on income or wealth?

It is one thing to justify the efficiency of a tax on consumption, it is another to justify its superior efficiency $v i s-\grave{a}$-vis a tax on income or wealth. Superior efficiency does not follow from efficiency. For instance, tax structures on income or wealth can become so quickly confiscatory that conspicuous consumption will be reduced in larger proportions than offered by any tax on consumption. Also, if the problem is positional externality, why not capping income and wealth through regulation? In short, why taxing consumption is the preferable option?

In the literature, the principle of 'neutrality' or 'non-discrimination' between consumers and savers advocates for consumption as a more appropriate tax base than income. ${ }^{14}$ According to Mill, taxing income leads to a double taxation of the savers (Mill 1848, V, I, 4): first, when they earn their income, even if part of it is invested, and, afterward, on the return of this investment. ${ }^{15}$ Beyond the 'unfairness' to agents in proper (Andrews 1974), i.e. the advantage given to some lifestyles over others, this absence of neutrality is detrimental to private and public savings and investment, i.e. efficiency.

The last point is the reason Frank emphasizes in support of substituting a tax on consumption to the current US tax system: reducing positional externalities without disincentivizing economic activities. If consumption is taxed at a steeply progressive rate, individuals will save more, which will positively affect investment and economic growth. Moreover, work will not be discouraged since the accumulation of wealth and investment will be rewarded.

Then, efficiency justifies taxing consumption, instead of income, since it helps to tame positional externalities while not de-incentivizing agents to engage in productive

\footnotetext{
${ }^{14}$ For a brief criticism of this idea, the reader could read the few pages written by Alvin Warren (Warren 1979-1980, pp.1097-1101).

15 Under non-idealistic conditions, income tax may be discriminatory between different types of savings, for instance if there is a realization requirement for savings for becoming tax liable like it is the case in United States (McCaffery 2002, pp.28-29).
} 
activities and, furthermore, incentivizing them to invest. But, Frank's conception of efficiency, as well as common defences of consumption tax, appears to include more than a consequentialist calculation. A "thicker" normative ideal seems to inspire the choice of consumption as the appropriate tax base: the idea that consumption is wasteful, especially in affluent societies. Furthermore, consumption is presented as being the source or vehicle of perverse social interactions implying signalling and counter-signalling, status-seeking, ratraces, etc. (James 2007; Schor 1998).

The taxation of consumption is, at least partly, driven by an underlying moral commitment to anti-consumerism or by an ascetic ideal according to which consumption should be directed at the satisfaction of basic needs, the rest often being superfluous or harmful. This commitment would explain the heavy emphasis on non-positional goods such as family, social relations, environmental concerns, altruism and generosity. Such emphasis would not be fully explainable by efficiency alone, but by a deeper conception of what has value in life. ${ }^{16}$

Without detailing further this idea, the conception of efficiency that underlies Frank's position could be summarized as it follows: an efficient society is a society that keeps consumption under control at the benefit of more valuable economic activities, like saving and investing, and non-economic ones, like spending time with friends and family. In short, efficient social cooperation is cooperation that maximizes the cooperative gains in both material and subjective terms, productive and non-productive terms.

\section{Paternalism}

Human frailty is the source of a second justification for taxing consumption. Because individuals often fail to adequately perceive or pursue their good, taxing consumption will be justified. To a certain degree, this argument elaborates on the psychological costs highlighted in the previous section. But it is paternalistic in the sense that public intervention is rooted in people's own good: individuals will be made better off by the imposition of a tax on consumption that 'would greatly enhance every citizen's opportunity to pursue independent visions of the good life' (Frank 1999, p.224).

\footnotetext{
${ }^{16}$ This is particularly visible in the literature on happiness and sustainability, ranging from voluntary simplicity to psychological studies on materialism (Kasser 2003). The point of interest is that literature is tangential to Frank's works, who regularly refers to it for backing up some of his points.
} 
Two versions of the argument may be differentiated, each based on a different view on the dynamics at work in conspicuous consumption.

(1) Individuals suffer from defects in their capacity to perceive their own good. The research on perceptive and cognitive biases supports this view (Ariely 2008; Kahneman 2011; Stanovich 2009): biases lead individuals to commit evaluative mistakes and act upon them, which is detrimental to their well-being. For instance, they tend to under-save in prevision of their future retirement. So it is then necessary to incentivize them to do so. Compulsory contributions to pensions constitute forced savings that one can justify by paternalistic reasons. Likewise, a consumption tax will force individuals to downscale their positional spending.

This view is nonetheless problematic. First of all, it conflicts with Mill's harm principle that justifies interfering only for preventing harms to others, not self-harms (as put by Mill: 'his own good, either physical or moral, is not a sufficient warrant'). As such, the first view subverts the externality rationale. In response, it may be argued that: first, individuals actually cause harms to each other, not only to themselves (the positional externalities), and, second, they cannot downscale their spending without external help.

A second objection is that the postulate of individuals suffering from biases may justify abusive interference in individual lives since, in the absence of further qualifications, the only condition is to single out self-inflicted harms of any sort. As for any slippery slope argument, it may be replied that the problem is not public intervention, but abusive public intervention, which can be fixed by establishing strict rules, in particular in regard to what should count as morally relevant self-inflicted harms. For being fully convincing, the second objection should demonstrate that taxing consumption represents an instance of abusive intervention perse.

Lastly, public intervention may handicap or even jeopardize ways of life that imply self-harm (e.g., extreme sports, unhealthy lifestyles), but which are freely chosen or endorsed by individuals. An additional argument is to claim that this kind of justification for public policy could easily become the vehicle for political perfectionism, i.e. the external imposition of a full-fledged comprehensive doctrine upon a given population. Against this, it may be replied that fully unconstrained lives are impossible: all individual decisions are bounded in one way or another by other people choices and institutional regulation. So the relevant 
question is: how much constraint can be justified? Does a tax on consumption excessively burden some individuals or groups? In fact, the only agents who might object are highspenders. Without going further, it should be noticed that Frank precisely shows how a consumption tax will be both individually (e.g. saving resources) and collectively beneficial (e.g. public goods).

But the main shortcoming of this version of the paternalistic justification is probably the assumption that individuals cannot, as a general rule, perceive their own good. Actually, it only takes to demonstrate that individuals may perceive their good for undermining the first version. In any case, Frank's case does not require such a stringent assumption.

(2) The second view holds that individuals are capable of perceiving their good, but experience difficulties in pursuing it because of the structure of social interactions. Individuals would rather consume less (especially positional goods), work less, spend more time with their relatives and friends, but they simply cannot. They must adjust to social patterns of consumption, appear "adequate" in situations (job interviews, professional meetings, social gatherings, community events, etc.), bid up for a home close to an excellent school, etc. The problem is by adjusting to social standards each individual raises the bar for everyone else. Regulation is justified, not by self-inflicted harms, but by the individual inability to cease the production of mutual harms conveyed by positional consumption.

Thus, the awareness of the existence of mutual harms does not guarantee that individuals will curb their positional spending. Individuals cannot stop spending because positional consumption is essential for securing important life opportunities (e.g. getting promoted, sending kids to excellent schools, networking with the 'right' persons, etc.) and because they may think that, at the end, they could outperform their competitors on consumption grounds. An incremental tax on consumption is meant to solve this collective action problem by changing the rules of the game: increasing the price of positional consumption and reducing the relative price of alternatives (non-positional activities).

In sum, the second justification for taxing consumption is that because individuals cannot opt out of positional dynamics (except at high cost), taxing consumption will make 
them better off on their own terms. ${ }^{17}$ But this second version of the paternalistic argument is not free of concern.

First of all, depending on how much of individual spending is actually determined by social patterns, the incentive of a tax on consumption may be reduced or annihilated. If we take seriously the idea that positional consumption is led by relative concerns and social patterns from which it is extremely difficult to escape, imposing a (incremental) tax on consumption may further harm individuals, especially the most vulnerable, by imposing an additional burden (the tax amount).

Secondly, it may be claimed that positional consumption qua consumption is necessary for economic growth. Some aspects of consumption could be individually and collectively detrimental, but the global effect would still be positive: the economic stimulus arising from positional consumption would generate more individual and collective benefits than harms (e.g. created jobs, increased taxes). Economic theories like Keynesianism even consider that consumption is the engine of economic growth and development. Therefore, curbing consumption would harm the economy and individuals.

At the end of the day, paternalism is controversial when it comes to justify a tax on consumption, as most of the other reasons for taxing consumption are. Before presenting the idea that the choice of a tax base expresses an underlying view on social cooperation, it is necessary to consider equality.

\section{Equality}

The third argument is that a consumption tax will help fighting inequalities, which have been rising in most industrialized countries since 1970's. Frank is concerned with income and wealth inequalities (Frank 2007, pp.7-16). For instance, he notes that between 1979 and 2000, the top $1 \%$ households increased their income by $201 \%$ against $9 \%$ for the bottom $20 \%, 13 \%$ for the second $20 \%, 15 \%$ for the middle $20 \%, 24 \%$ for the fourth $20 \% .{ }^{18}$ His 'point is not that the creation of these big fortunes is by itself a bad thing' (Frank 2007, p.15), but that

\footnotetext{
17 This second justification generates additional difficulties regarding the potential consequences on the kind of policies that could be conducted. Since positional externalities are partly evaluated according to some subjective standards, tax on consumption may lead to politics of envy.

18 The most recent evidence shows that the trend has worsened in the United States (Stiglitz 2013). Furthermore, this spread between the very top-incomes and the rest of the income-earners is not proper to United States, but has become common in a lot of (if not all) industrialized countries (OECD 2011).
} 
inequalities harm the middle class by increasing a variety of costs, jeopardizing heath, etc. More specifically, inequality also aggravates positional harms. Therefore, if one cares about positional externalities, one should care about inequalities. Equality has however no intrinsic value within Frank's framework. The perspective of egalitarian societies with high levels of positional spending is not terribly attractive for Frank.

Positional competition in a context of rising inequalities generates harms or worsens existing ones (Frank 2007, pp.92-102). Individuals work longer hours that they are willing to for keeping up with increased positional expenditures in a context of stagnation of real incomes. They also reduce their savings and increase their debts (e.g. by abusing of credit card payments). Since it has been expensive to live inner cities, they commute farther and longer, which incurs stress and sleep deprivation.

From the perspective of equality, a tax on consumption should nonetheless respond to a serious objection, especially if it is supposed to replace other taxes, on income or wealth: it will favour rich people since they will accumulate wealth at an exorbitant rate, in particular in a situation, as assumed by Frank, of rising income inequalities. By the way, the idea is largely acknowledged that large concentrations of wealth can undermine democracy and that one of the first functions of taxation is not to tame this tendency (Avi-Yonah 2002; Rawls 2001, p.279). If consumption alone is taxed, nothing prevents a handful of individuals of accumulating vast material resources that can be transformed into political power at the service of their own interests. ${ }^{19}$

Two answers are possible. The first is to say that accumulation of wealth is not equivalent to actual exercise of power. The second is to point out that a tax on consumption primarily aims at taming positional concerns and their deleterious effects, not at enforcing any kind of equality, especially of wealth, power or capacity to influence.

On the one hand, it is exact that accumulation of wealth is not the same than actual use of wealth for exercising influence. But great wealth, if it does not automatically lead to concrete use of power, still represents what neo-republicanism labels as the capacity to arbitrarily interfere in citizens' life. Even if extremely wealthy individuals act virtuously, i.e. respect established laws and democratic rules (in regard, for instance, of the independence of

\footnotetext{
19 This objection is not an argument against consumption tax, but against the consumption as the unique tax base, which is different. A tax on consumption can be mixed with other tax bases, but by doing so, the originality of the defences of consumption tax as Frank's one is lost.
} 
elected representatives), they will still have the capacity of interfering (or they might be induce to do so by other agents who have an interest in their interference). Hence great accumulations of wealth are sources of domination (Pettit 1999), which threaten democratic institutions.

On the other hand, one may answer that the tax on consumption should be evaluated on its own grounds: the good that it promises to deliver. Since it does not promise to deliver equality of wealth, it is unfair to judge it on this criterion. The purpose being to curb positional externalities, it is then difficult to deny that consumption tax has some credential for this purpose.

However, part of the defence of a consumption tax as articulated by Frank is to interpret positional harms from the perspective of subjective well-being. It is then difficult to argue that a tax system that will limit conspicuous consumption, while leaving impressive accumulations of wealth, will fairly fulfil its purpose on its own grounds. Actually, the evidence mobilized by Frank demonstrates that people psychologically suffer from relative standing, including wealth disparities. Without even taking into account subjective wellbeing, it could be presumed that a society that will tolerate large wealth inequalities will nurture distrust among its members along with other social bads (Uslaner 2002; Wilkinson and Pickett 2010). This could impair social cooperation, which is at the core of Frank's conception of efficiency.

Finally, taxing consumption, especially at a steeply progressive rate, may have antiegalitarian results, depending on the design of the tax. Individuals might actually have high levels of spending for reasons that are not positional and without producing positional externalities. For instance, people may suffer from chronic diseases, be handicapped or need to look after dependents, which implies higher levels of consumption. A tax will represent a sanction imposed on their unlucky condition. ${ }^{20}$ People may accrue consumption for genuine reasons (again, handicap, sickness, dependent, etc.) by relying on credit. They will be harmed

\footnotetext{
${ }^{20}$ One might claim that this problem flows from the insensitivity of consumption tax to brute bad luck. The same person might argue that equality imposes not too worsen the situation of those who suffer from bad brute luck, i.e. who suffer from inequalities due to no reason of their own (Knight 2009).
} 
in several ways: the material cost, the psychological suffering (of the initial handicap, sickness, etc., of the material incapacity to cope with it), the incurred debts and the tax. ${ }^{21}$

These objections illustrate that a commitment to equality may be at odds with consumption as the appropriate (and unique) tax base. Despite the fact that Frank seems to worry about growing inequalities, his argument is rather instrumental than intrinsic: equality is not a good in itself, it is a source of concerns insofar that it exacerbates positional competition (which aggravates the situation of the worse-off and the middle-class). The force of appealing to equality for justifying a tax on consumption is limited. Furthermore, it is possible to consider that equality is an argument against taxing consumption (especially at a progressive rate) or, at least, against consumption as the only tax base since it may actually worsen some inequalities (material and political).

\section{Two Conceptions of Social Cooperation}

A tax on consumption raises various objections, especially if it should replace other tax bases as suggested by Frank and others (McCaffery 2002). These objections are useful because they offer opportunities for judging of the strength of different arguments for a tax on consumption. Equality provides a shaky ground since endorsing equality may lead to object to the principle of a (unique) tax on consumption while a (unique) tax on consumption may still not be fully justified by equality. Paternalism generates different objections, some stronger than others. Still, the global impact on individuals' well-being needs to be further assessed. Finally, the efficiency argument underlines the value of social cooperation for justifying a (progressive) tax on consumption.

Derived from the idea of the normative thickness of efficiency as an argument for justifying a tax on consumption, my final claim is that the choice between taxing consumption, income or wealth reflects a parti pris between different conceptions of social cooperation. The issue of taxation is not a purely material question about how to provide resources to public finances. Taxation enounces individuals' financial responsibilities $v i s-\grave{a}$-vis the political community, understood as a nexus of cooperative mechanisms. It spells out the "right" distribution of contributions among citizens according to a conception of the proper

\footnotetext{
${ }^{21}$ Depending on the design of the tax scheme, this shortcoming may be worsened by the steep progressivity proposed by Frank and others. There could also be correcting mechanisms external to the tax scheme, e.g. through hypothecation (see Daniel Halliday's contribution to this volume).
} 
terms of cooperation. The fundamental choice of a tax base indicates how social cooperation is collectively understood and enforced.

The scarce works on taxation in political philosophy usually downplay this aspect. For instance, Liam Murphy and Thomas Nagel consider that the choice of a tax base is only instrumental for economic justice. They invoke the 'fair distribution of the burdens' (Murphy and Nagel 2002, p.98) or 'just social outcomes' (Murphy and Nagel 2002, p.99) as guiding principles for determining how to tax citizens. Taxation would be an instrument for reaching an ideal that is defined independently of what taxation is about.

There are several problems here. Firstly, a "fair distribution of the burdens" and "just social outcomes" are two different things and nothing guarantees that a fair distribution of the burdens advocates for the same tax arrangement than one that produces just social outcomes. Secondly, in themselves they are silent on what fairness and justice should be. Presumably, different conceptions will lead to significantly different tax designs. Thirdly, the view implicitly endorsed by the authors is that, at the end of the day, any tax base could be used for promoting any political ideal. Taxation would be a plastic, value-free, tool for pursuing political ideals.

But it may be argued that the choice of a tax base is not only a practical choice to be made under the light of a pre-existing conception of economic justice. It may be claimed that each of the three major tax bases - wealth, income and consumption ${ }^{22}$ - tells a different story about how to conceive social cooperation, what are our (material) responsibilities and how we should relate to each other. Basically, a wealth tax is based on the idea that it is appropriate to tax individuals on what they own, an income tax on what they earn and a consumption tax on what they use for non-productive purposes.

This moral dimension appears in the discussions about the "common pool" metaphor, which is recurrent in the debates about taxation (Warren 1979-1980, pp. 1094-1095). Since society is a common pool of resources, individuals may be taxed according to their share of (wealth tax), contribution to (income) or use of (consumption) the common pool. The terms of the metaphor suggest that it is preferable to tax people on how much they take out of the common pool instead of how much they put in (Kaldor 1955, p.53; Rawls 1985, p.278).

\footnotetext{
${ }^{22}$ We leave aside inheritance tax, which can be classified under other categories (e.g. wealth or income).
} 
If we put aside its debatable cogency (Murphy and Nagel 2002, pp.109-112), the metaphor has the merit to highlight the normative nature of the choice of a tax base. While many egalitarians take from granted that contributions to public resources should reflect one's ability to pay, only the wealth tax respects this principle. If we put wealth aside in order to contrast income and consumption taxes, it becomes clear that they represent different visions of social cooperation.

(1) Income tax (i.e. revenues from labour and capital) bears on fluxes supposedly correlated with wealth creation. Individuals are presumed to receive an income reflecting their productivity. Their contribution to social cooperation through taxation should be calculated on this basis.

What the common pool argument gets right is that income tax expresses a financial liability that partly depends on individual contributions to the collective resources. But it only partly depends on individual contributions since it is reasonable to consider that a given individual's productivity has a spillover effect on others' productivity. As a result, the distant resources (the positive externalities) that a given individual has contributed to generate are not accounted for in her income (whereas her income also encapsulates others' distant contribution). However the fact that tax contributions are roughly correlated to the value one has contributed to create does not mean that one's taxes should be understood as being justified by (or bearing on) the value created by individuals. It is quite a different question.

Since society is a vast system where different cooperative mechanisms are intertwined, one's income (when based on productivity) reflects one's own work, but also one's use of cooperation, i.e. the work of other individuals. Taxing income can be understood not only as a tax levied on one's contribution to the common pool, but also as a tax levied on one's use of cooperative mechanisms during the process of creating value. ${ }^{23}$ This reformulation expresses a conception of social cooperation where individuals' contributions to public goods, redistribution and public insurance are calculated by combining individuals' productive capacity and use of cooperative mechanisms. ${ }^{24}$

\footnotetext{
${ }^{23}$ According to this view, the positive correlation between the tax and income (under flat or progressive tax rates) could be justified by the fact that, presumably, the more individuals earn, the more they are likely to have benefited from social cooperation.

24 Even if the paper makes an analytical distinction between one's capacity to produce and one's use of cooperative mechanisms, it remains an open question whether the two can be distinguished in the facts, whether individuals' productivity can be measured and, furthermore, if it makes sense to talk about "one's productivity" in most of cooperative settings due to the intense division of labour that characterizes modern economies.
} 
(2) Consumption tax bears on one's use of her income, i.e. her income minus savings. It relates to one's use of the created wealth. While an income tax defines one's duties to contribute to public resources as depending on her ability to produce value and her use of cooperative mechanisms, consumption tax adjusts contributions to her actual use of the wealth that has been produced. A manner to flesh out this idea is to claim that since world resources are limited, it is legitimate to hold people liable for the resources they extract from the world, especially when these resources are scarce.

A tax on consumption links one's contributions to her degree of use of collectively produced wealth. Since this use depends on preferences, it is reasonable to postulate that consumption tax tells a story on social cooperation that emphasizes the legitimacy of individual contributions that match the goods and services that individuals decide to extract from social cooperation. Also, a tax on consumption does not make individuals liable for the wealth they put aside (i.e. savings) since it does not strain the common resources. In short, a tax on consumption tends to see individual choice about the use of common resources as the normatively relevant criterion for establishing one's tax duties.

\section{Conclusion}

The previous developments nurture more questions than responses. But they unveil issues that are fundamental for the ethics of taxation. The main is the moral significance of the tax base: any solid defence of a given tax base needs to flesh out the underlying conception of social cooperation since it is where the moral force of the argument stands. In short, by taxing individuals on certain terms, the political community tells a particular story about our mutual duties. This illustrates the need for a full-fledged normative analysis of the various models of social cooperation embodied in the different tax bases. The only ambition of this chapter was to introduce to the relevance of such a project in political philosophy.

Without enumerating all the tasks encapsulated in this project, another challenge is to clarify the moral status of individual preferences within the model of cooperation entailed by the choice of consumption as a tax base. The rationale exposed above suggests that individuals are materially liable for their preferences since they determine their spending habits. However the preferences that determine one's contribution are what could be called realized preferences. Taxing consumption is taxing individuals on the preferences they 
succeed to satisfy under constraints (e.g. budget, availability of alternatives and substitutes). It means that individuals are not taxed on their preferences, but on the overlap between them, their capacities and the options that are available at the time of the choice.

The moral status of individual choice (and individual responsibility) in tax duties is a major research theme for the ethics of taxation (as it is already the case for distributive justice as epitomized by the debates around luck egalitarianism (Knight 2009)), especially because the strength of the case for a consumption tax is deeply indebted to the intuition that taxing people on their choice is the right thing to do: since people decide to spend their money on certain goods and services at a certain level (so, they decide the kind and the intensity of the strain they impose on social resources), it is legitimate that their contribution account for that. But individual spending is actually determined by a mix of chosen and un-chosen preferences, a mix of choices and circumstances, which is difficult to disentangle. Individuals control only a part of their spending, the other part being affected by their needs. Thus, a defence of a consumption tax needs to address the following issue: is it fair (or simply justified) to tune one's contribution to social cooperation on factors that may be outside her control to a very large extent? 


\section{References}

Andrews, William D. 1974. A Consumption-Type or Cash Flow Personal Income Tax. Harvard Law Review 87 (6):1113-1188.

Ariely, Dan. 2008. Predictably Irrational: The Hidden Forces that Shape Our Decisions. New York: HarperCollins.

Avi-Yonah, Reuven S. 2002. Why Tax the Rich? Efficiency, Equity, and Progressive Taxation. The Yale Law Journal 111 (6):1391-1416.

Baumol, William J. 1952. Welfare Economics and the Theory of the State. London: Longmans, Green and Co.

Baumol, William J. 1972. On Taxation and the Control of Externalities. The American Economic Review 62 (3):307-322.

Botton, Alain de. 2004. Status Anxiety. New York: Vintage Books.

Brams, Steven J. 1985. Superpower Games: Applying Game Theory to Superpower Conflict. New Haven: Yale University Press.

Daunton, Martin. 2002. Just Taxes: The Politics of Taxation in Britain, 1914-1979. Cambridge: Cambridge University Press.

Delalande, Nicolas. 2011. Les Batailles de l'impôt. Éditions du Seuil.

Demsetz, Harold. 1969. Information and Efficiency: Another Viewpoint. Journal of Law and Economics $12(1): 1-22$.

Dixit, Avinash, and Barry Nalebuff. 1993. Thinking Strategically: The Competitive Edge in Business, Politics, and Everyday Life. New York: Norton.

Frank, Robert H. 1999. Luxury Fever: Why Money Fails to Satisfy in an Era of Excess. New York: Free Press.

Frank, Robert H. 2007. Falling Behind: How Rising Inequality Harms the Middle Class. Berkeley and Los Angeles: University of California Press.

Frank, Robert H. 2008. Should Public Policy Respond to Positional Externalities? Journal of Public Economics 92 (8-9):1777-1786.

Frank, Robert H. 2011. The Darwin Economy: Liberty, Competition, and the Common Good. Princeton: Princeton University Press.

Hirsch, Fred. 1976. Social Limits to Growth. New York: Routledge. 
James, Oliver. 2007. Affluenza. London: Vermilion.

Kahneman, Daniel. 2011. Thinking, Fast and Slow. New York: Penguin.

Kaldor, Nicholas. 1955. An Expenditure Tax. London: Uwin University Books.

Kasser, Tim. 2003. The High Price of Materialism. Cambridge: MIT Press.

Knight, Carl. 2009. Luck Egalitarianism: Equality, Responsibility, and Justice. Edinburgh: Edinburgh University Press.

Landes, Xavier. 2013a. Pigouvian Taxation. In Encyclopedia of Corporate Social Responsibility, eds. Samuel O. Idowu, Nicholas Capaldi, Liangrong Zu, and Ananda Das Gupta, 1846-1853. New York: Springer.

Landes, Xavier. 2013b. Positional Concerns and Institutions: Some Arguments for Regulation. Central European Journal of Public Policy 7 (2):60-87.

Landes, Xavier, Martin Marchman, and Morten Nielsen. 2013. The Academic Rat Race: Dilemmas and Problems in the Structure of Academic Competition. Learning and Teaching: The International Journal of Higher Education in the Social Sciences (LATISS) 5 (2):73-90.

McCaffery, Edward J. 2002. Fair Not Flat: How to Make the Tax System Better and Simpler. Chicago: Chicago Press.

Mill, John Stuart. 1848. Principles of Political Economy: With Some of Their Applications to Social Philosophy. Boston: C.C. Little and J. Brown.

Mill, John Stuart. 2003. On Liberty. New Haven and London: Yale University Press.

Murphy, Liam, and Thomas Nagel. 2002. The Myth of Ownership : Taxes and Justice. New York: Oxford University Press.

OECD. 2011. Divided We stand: Why Inequality Keeps Rising: OECD Publishing.

Pettit, Phillip. 1999. Republicanism: A Theory of Freedom and Government. New York: Oxford University Press.

Rawls, John. 1985. Justice as Fairness: Political not Metaphysical. Philosophy and Public Affairs 14 (3):223-251.

Rawls, John. 2001. Justice as Fairness: A Restatement. Cambridge: Belknap Press.

Schor, Juliet B. 1998. The Overspent American: Why We Want What We Don't Need. New York: Basic Books. 
Solnick, Sara J., Li Hong, and David Hemenway. 2007. Positional Goods in the United States and China. THe Journal of Socio-Economics 36 (4):537-545.

Stanovich, Keith E. 2009. Decision Making and Rationality in the Modern World. New York: Oxford University Press.

Stiglitz, Joseph E. 2013. The Price of Inequality: How Today's Divided Society Endangers Our Future. New York: W. W. Norton \& Company.

Uslaner, Eric. 2002. The Moral Foundations of Trust. Cambridge: Cambridge University Press.

van den Bergh, Jeroen C.J.M. 2010. Externality or Sustainability Economics? Ecological Economics 69 (11):2047-2052.

Van Kempen, Luuk. 2009. Status Consumption and Poverty in Developing Countries. Saarbrücken: VDM.

Veblen, Thorstein. 1994. The Theory of the Leisure Class. Mineola: Dover Publications.

Warren, Alvin. 1979-1980. Would a Consumption Tax Be Fairer Than an Income Tax? The Yale Law Journal 89 (6):1081-1124.

Wilkinson, Richard, and Kate Pickett. 2010. The Spirit Level: Why Equality is Better for Everyone. London: Penguin. 